\title{
Tomasz Żaglewski
}

\section{The doom of the Fantastic Four: Marvel's First Family disappearance and what it says about the transmedia perspective of popular comics}

\begin{abstract}
History of the media migration of the Fantastic Four brand is almost as dramatic as the most thrilling adventures of Stan Lee's and Jack Kirby's original superhero team. Initially one of the most influential comic book characters in American history, and generally a foundation for the whole Marvel Universe, the team of four exceptional characters went through various versions of TV shows, cartoons, video games and finally cinematic features. However, unlike other Marvel properties, such as Spider-Man or X-Men, the Fantastic Four has never achieved much recognition from other media properties, with the blame being put mostly on the ridiculous film presentations created by Roger Corman or Josh Trank. But there is a different, hidden story behind Fantastic Four's outside-comic's failures, which underlines the perception of the American popular comic book as highly dependent on cultural, economical and multimedia-oriented shifts. If we assume that the superhero comic is a strictly paratextual and transmedia phenomenon, and the history of that genre suggests nothing different, then on the basis of the Fantastic Four example we can observe how a modern politics of managing a comic brand like Marvel relates to property-rights struggles (i.e. between Marvel and Fox Company), a fan perception that is shaped more and more by the comic-based extensions and finally how the comic book itself, being still a major inspiration for the modern audiovisual culture, loses against transmedia storytelling rules. In my essay, I would like to concentrate on the question of why the Fantastic Four comic title vanished after the recent Secret Wars crossover event and what the categories of synergy, franchising, transmedia narration and convergence have to do with the landscape of a modern popular comic.
\end{abstract}

Keywords: Marvel, Fantastic Four, convergence culture, transmedia storytelling

In September 2015 many Marvel comics readers could have experienced quite a shock. Besides the disturbing signs that were being sent from Marvel Comics since the post-Secret Wars (2015 Marvel crossover) rumors of narrative consequences, it now became official that there will be no more place for the popular 
$X$-Men-related titles in the future offer of the publisher. This suggestion — as smashing for the fans as it was - was not very unexpected for those deeply interested in Marvel's publishing policy over the last decade. The X-Men comics became another victim of a new business strategy that came with the worldwide success of Marvel's properties through the Marvel Studios cinematic presentations. At the same time, it became clear that the Marvel corporation, now newly re-discovered in the field of cinema, will invest in expanding the comics franchises on the non-comics markets. This was connected with another tendency that finally evinced itself in the form of a prophetic cancelation of the mutant's graphic series - that is, with the absolute diminishing of those comic characters that had had theirs commercial rights formerly passed to another corporation (in most cases the biggest financial issues arose between Marvel and Sony/Fox properties). The story of these unsettled politics is quite rich and some of its aspects will be reviewed by me in the following article. To put it briefly, in the middle of the 1990s, in the face of the comics-industry recession Marvel tried to save itself by selling the rights to its famous characters to movie studios. $X$-Men characters, as well as Fantastic Four ones, became a part of Rupert Murdoch's entertainment empire and finally ended up in Bryan Singer's blockbuster X-Men (2000), which is believed to have actually started the whole superhero rebirth in modern cinema. However, in over a decade Marvel Studios became a major cinematic power itself and that is the main reason for today's X-Men comics twilight. As Kit Simpson Browne has noted about the end of mutants in Marvel history:

Well, on the one hand, it's an intriguing and potentially creatively successful new plot-line, one which could prove to be an engaging, innovative and well-liked new take on the mutant-focused part of the Marvel comic-book universe. On the other hand, though, it looks an awful lot like the continuation of an active campaign by Marvel to undermine a very particular chunk of its comic-book domain. Specifically, the comic-books to which Fox holds the film rights: The X-Men, and the Fantastic Four. ${ }^{1}$

It is true, however, that a full interpretation of the cancelation should be considered through the case of Fantastic Four $(F F)$ as the first major publishing shift made by Marvel according to the new synergistic logic. For that reason the main goal of my article is to describe a "negative zone" (term associated with the important for $F F$ comics fictional dimension) of synergy, where all transmedial devices are actually used to suppress a popular franchise just like all matter in the fictional Negative Zone is striving to be negatively charged. This article, however, should be treated more like a historical review of Marvel-Fox economical and textual rivalry since the official acquisition of 21st Century Fox company by Disney took place on 20 March 2019 and ended the $F F$ 's "exile." With a new comic book series started in August 2018, Marvel's "First Family" of heroes had returned to Marvel's port-

${ }^{1}$ K.S. Browne, "There will officially be NO MORE X-Men in Marvel comics," Movie Pilot, http://moviepilot.com/posts/3550221 (accessed: 27.07.2016). 
folio, which actually does not cancel the consequences of previous "secret wars" between the two companies over the popular superhero brand.

According to the fundamental piece of academic research that tries to deconstruct the structure of a transmedial narration - that is, Convergence Culture: When Old and New Media Collides by Henry Jenkins - we can distinguish four basic strategies for creating such a model. According to Jenkins, the most important mechanisms are: synergistic storytelling, collaborative authorship, the art of world-making and additive comprehension. For my research here I will concentrate only on the first strategy, which is the most important factor for the case of $F F$ as the politics of synergy are mainly responsible for some comics titles' termination. It is important to note that besides the negative aspect of synergy, which becomes clear when we look at both $X-M e n$ and $F F$ examples, it is at the same time not a sufficiently described problem as most of the academic titles appear to be quite an "optimistic" vision of synergy itself. According to Jenkins:

Soon, licensing will give way to what industry insiders are calling co-creation. In co-creation, the companies collaborate from the beginning to create content they know plays well in each of their sectors, allowing each medium to generate new experiences for the consumer and expand points of entry into the franchise. ${ }^{2}$

It is hard not to notice signs of corporate struggles that may appear during the inevitable, according to the author, co-creative future. Even the more modern observations seem to have great faith in the possible benefits of the industry's co-operation that gives to its participants, as Derek Johnson is suggesting, "the industrial promise of synergy, where the same content can dominate multiple markets and generate more value than the sum of its iterative parts." 3 In my opinion, however, it is not entirely accurate to follow these dominant discourses of expansion and growth, that may be found in most of the analyses, as we should try to concentrate more and more on the "dark side" of synergy that may appear just as it is present in the Marvel instantiation.

The case of $F F$ comics and its publishing annihilation is even more controversial than the fatal fate of the $X$-Men. Basically, the $F F$ title is not just one of Marvel's many popular properties but Marvel's very first commercial and artistic hit that started in November 1961 with the original FF initial issue (boldly and quite accurately called The World's Greatest Comic Magazine). The successful, for most of the time, timeline of $F F$ publications ended in April 2015 with the last adventure of Marvel's First Family. It would be quite unfair, however, to blame only the diminishing quality of $F F$ comics - and lowering sales as well - over the last few years for the decision of abandoning the series by Marvel's publishers. There is another, hidden story behind the $F F$ overture that once again should draw

${ }^{2}$ H. Jenkins, Convergence Culture: When Old and New Media Collides, New York 2006, p. 105.

${ }^{3}$ D. Johnson, Media Franchising: Creative License and Collaboration in the Culture Industries, New York 2013, p. 67. 
our attention to the middle of the 1990s. The year 1995 is a very important year for the American comic book industry - it is the time when the so-called speculation bubble burst in the comics market, which was a direct consequence of the earlier comic book collector's craziness in the USA. It created a very risky assumption that popular comics can exist as an investment object, which resulted in an increase in sales and its final crash when the "unique" copies of stories such as Death of Superman turned out to be quite worthless. For the biggest American publishers - DC Comics and Marvel - this unexpected crisis ended with searching for new business strategies that were supposed to assure some kind of survival during the coming years of recession. Marvel chose a retreat from the self-franchising strategy, which was implemented by the company at the beginning of the decade, towards a license-oriented model that required, as I have written before, some forms of co-operation between Marvel and other companies. As Johnson pointed out:

Analysts noted that Marvel's conscious decision to produce intellectual properties, rather than the products derived from them, spared Marvel from having to risk massive capital investments on its own [...]. In a business model based in licensing, profits had to be split, with the producer-distributors that licensed Marvel characters receiving the lion's share. ${ }^{4}$

A strategy that happened to be a lifebelt for the comics publisher at the end of the 20th century - when comic book properties seemed to be unattractive for the general consumer - appeared to be a financial harakiri just a decade later, when Hollywood's biggest blockbusters such as Sam Raimi's Spider-Man trilogy or Bryan Singer's $X$-Men saga were generating massive revenues. The middle of the 2000s became a time of Marvel's battle to regain the formerly sold licenses.

The effort to re-establish popular titles such as Spider-Man or FF as strictly Marvel-directed franchises was definitely logical. As the example of Blade (dir. S. Norrington, 1998) proved, even the second-class characters from the Marvel comic universe had a significant power in the cinematic box-office - it was a clear assumption then that even more recognizable heroes such as Spider-Man would establish solid out-of-comics franchises (as it eventually happened with Sony Pictures features). $F F$, which was the property sold-out alongside $X$-Men to Fox, had already quite a successful run as a series of multimedia productions and thanks to that seemed to be a ready-to-explore cinematic brand. On the basis of television, $F F$ started its "TV adventure" in a very popular animated show titled simply Fantastic Four, produced by Hanna-Barbera, that ran for 20 episodes on ABC channel from 9 September 1967 to 15 March 1970. The second cartoon iteration of the First Family appeared in a production by DePatie-Freleng, which ran for just 13 episodes from 9 September 1978 to 16 December 1978. This series, however, was quite an interesting one in the history of the franchise - it features a H.E.R.B.I.E. Unit, an E.T.-like robot, in place of the Human Torch that was

\footnotetext{
${ }^{4}$ Ibid., p. 95.
} 
removed from the cartoon. FF returned as a part of The Marvel Action Hour TV feature. It was a part of Marvel's very successful television offensive that was accompanied by such cult cartoons as Spider-Man or Iron Man - both produced for the Fox Kids channel. This series ran for 26 episodes from 24 September 1994 to 24 February 1996. The final animated adventure for FF, Fantastic Four: World's Greatest Heroes, debuted on 2 September 2006 on Cartoon Network and ran for 26 episodes.

Besides the mostly popular animated productions, $F F$ assembled also quite an impressive slate of cinematic productions - although the only impressive thing here is their amount and not quality. The infamous parade of $F F$ starts with "legendary" The Fantastic Four, completed in 1994 by producer Roger Corman. The film was not released, however, to theaters or on home video, but it has since been available only through bootleg video distributors and recently by torrent websites. It is an absolutely disastrous - both technically and narratively — effort made to bring the $F F$ to the big screen, which in collective memory remains Corman's another semi-professional distribution with a very small amount of creative effort. It seemed certain that at the beginning of the 21st century - alongside new technological tools and the newly introduced superhero craze in Hollywood - the possessor of the FF movie rights, 20th Century Fox film studio, will prepare a smashing cinematic presentation that the four extraordinary heroes surely deserve. As it happened, however, Fox's first two films gained modest box-office revenues with a smashing critics and audience reception at the same time. In 2005, FF was directed by Tim Story and released by 20th Century Fox. It earned $\$ 155$ million in North America and \$330 million worldwide. The sequel, Fantastic Four: Rise of the Silver Surfer, directed once again by Story was released in 2007. The sequel earned $\$ 132$ million in North America and a total of $\$ 330.6$ million worldwide. ${ }^{5}$ As Michael Rechtshaffen wrote about the first production for Hollywood Reporter:

In trying to nail just the right mix of comic book action, comedy and pathos, the movie emerges as a tone-deaf mishmash of underdeveloped characters, half-baked humor and unhatched plotting drenched in CGI overkill. ${ }^{6}$

It was just a prelude, however, to the underwhelming reception of the $F F$ reboot made by Fox in 2015. Directed by Josh Trank, it was released on 7 August 2015 and immediately received disastrous reviews, which resulted in revenues of only \$168 million worldwide. Having received an unbelievable 9\% score of positive reviews on the popular website rottentomatoes.com, Trank's $F F$ can be easily called one of the most disastrous comic book adaptations in history, which was probably best described by Rolling Stone's critic Peter Traves:

${ }^{5}$ All the box-office results after boxofficemojo.com.

${ }^{6}$ M. Rechtshaffen, "Press views: Fantastic Four," $B B C$, http://news.bbc.co.uk/2/hi/entertainment/4665469.stm (accessed: 27.07.2016). 
The latest reboot of the Fantastic Four - the cinematic equivalent of malware - is worse than worthless. It not only scrapes the bottom of the barrel; it knocks out the floor and sucks audiences into a black hole of soul-crushing, coma-inducing dullness. ${ }^{7}$

It is important to note here that even if Story's first two productions were made in a quite "peaceful" co-operation between Fox and Marvel (Marvel did not yet have their own movie company as well as the capital to self-produce a high-budget feature), Trank's movie was just on the frontline in a "battle of the cinematic universes" between Marvel Studios and Fox. It can be also described as a specific anti-synergetic model that surrounded this particular franchise. It is truly an inspiring and unusual example of fully conscious practices of one entertainment company that aims to undermine the property of another industry's subject, although the property itself originates from the first company's very own portfolio. However, the battle here is taking place not only over the obvious financial benefits but mostly over widening the catalogue of the superhero cinematic franchises and its narrative/commercial expansions. The two highly controversial issues between Fox and Marvel, namely FF and X-Men properties, generated concrete creative practices that seem to reduce once again the narrative and commercial abilities of the competitors. And so, by the rules of the copyright deals made in the 1990s, Marvel is unable to use the word "mutant" in any of their live-action films or TV series. Instead, their superpowered people are now called "gifted" (as in the Marvel Cinematic Universe productions such as Avengers: Age of Ultron). At the same time, Marvel is responding with $F F$ series being canceled and all the $X$-Men series recently paused. The publisher also officially killed off its most-beloved mutant (and the one with the most brand recognition with movie audiences) in a mini-series called Death of Wolverine, which was instantly perceived as another strike against the Fox Cinematic Universe. According to Brian Hadsell, the latest Marvel moves in the field of comic books publishing - as illogical as they seem by getting rid of popular characters - have a deeper meaning according to the highly glorified Marvel Cinematic Universe that happens to be the ultimate "canon" for the comics as well. As Hadsell suggests, "Iron Man, Thor, Captain America - these are the important guys. The Avengers matter. The Fantastic Four do not." ${ }^{8}$ In the battle between the companies, practical commercial tools are being used as well as

Marvel simply refus[ing] to lease Fox the merchandising rights for Days of Future Past. That's why you didn't see Wolverine, Magneto and Sentinel action figures in your local toy aisle: Marvel was willing to give up on a little bit of profit to starve Fox out of a boat-load of money. ${ }^{9}$

7 P. Travers, "Fantastic Four," Rolling Stone, http://www.rollingstone.com/movies/reviews/fantastic-four-20150806 (accessed: 27.07.2016).

${ }^{8}$ B. Hadsell, "Explaining Marvel's ongoing feud with Fox over the Fantastic Four and X-Men film rights," Unreality Magazine, http://unrealitymag.com/movies/explaining-marvels-ongoing-feud-withfox-over-the-fantastic-four-and-x-men-film-rights/ (accessed: 27.07.2016).

${ }^{9}$ Ibid. 
The most symbolical move from Marvel that was supposed to undermine the importance of now Fox-owned comic book characters came with the promotional materials, such as posters, etc., for celebrating Marvel's 75-years anniversary in 2015. As Hadsell noticed:

You can't find a single member of the Fantastic Four or the X-Men on this comic-book one-sheet. Is this a big deal? It's notable, primarily because characters like Wolverine and the FF were front and center back in $2007 .{ }^{10}$

The biggest aftershocks of the Fox-Marvel struggle reach the comic books themselves, which results in such drastic decisions as canceling the whole series, i.e. FF. As it happened, there is a wide spread of possible creative mechanisms that can be used to undermine a franchise whose cinematic benefits are serving a non-Marvel company. For example, it became quite a controversial piece of news in 2015 when one of the biggest Marvel writers in history, and the creator of the modern $X$-Men comic book universe as well, Chris Claremont, announced that he had received an official "doctrine" from Marvel's executives, which ordered him not to create any new $X$-Men characters in comics because Fox would have the rights to put them in their movies. The biggest narrative consequence that can be used as a form of a metaphor for the battle with Fox came, however, with Marvel's highly anticipated comic book crossover in 2015 called Secret Wars. According to the industry's insiders, the whole Secret Wars plot was planned as a final purification of Marvel's comic universe and a reduction of all the characters that are not in full management of the company. As Marvel's Executive Editor, Tom Brevoort, put it frankly:

If you had two things, and on one you earned $100 \%$ of the revenues from the efforts that you put into making it, and the other you earned a much smaller percentage for the same amount of time and effort, you'd be more likely to concentrate more heavily on the first, wouldn't you? ${ }^{11}$

Brevoort's intention becomes quite clear when we look at the consequences of the Secret Wars storyline for the Marvel comics. The biggest issue here is that Jonathan Hickman and Esad Ribić's massive plot definitely ends the history of $F F$. The group itself is split up: Reed and Susan Richards (Mr Fantastic and Invisible Woman) as well as their children Franklin and Valeria Richards are taking a break from being superheroes to be the scientists that they always were. There is a special form of homage here to these classic heroes as they are retained as the builders of new fictional universes behind the scenes, which refers to theirs actual origins as the beginning of the Marvel Comics very own universe in the 1960s. At the same time, the other members of $F F$, The Human Torch and The Thing, are kept alive and ac-

10 S. O'Connell, "Marvel still sabotaging X-Men and the Fantastic Four," https://www.cinemablend. com/new/Marvel-Still-Sabotaging-X-Men-Fantastic-Four-71801.html (accessed: 27.07.2016).

${ }^{11}$ R. Johnston, "Tom Brevoort semi-confirms reduction in prominence of X-Men at Marvel," Bleeding Cool, http://www.bleedingcool.com/2014/08/02/tom-brevoort-semi-confirms-reduction-inprominence-of-x-men-at-marvel/ (accessed: 27.07.2016). 
tive in Marvel's comic books, with the former appearing in Uncanny Avengers and Uncanny Inhumans series and the latter serving among the Guardians of the Galaxy - all three properties, let us add, fully controlled by Marvel.

The Secret Wars narrative strategy may be described as a kind of sabotage of the classical synergy model. Marvel's wisdom here, however, is to actually keep $F F$ members alive but not involved in Marvel Comics, which may become crucial in any future plans of regaining the movie rights from Fox and re-launching the comic title as well. Until then, Marvel continues to hold back on $F F$ licensing, which means no toys, clothes, books, art, etc. alongside with no new $F F$ books, which is a direct result of Hickman and Ribićs story. Probably the best coverage of $F F$ 's decline caused by the conflict with Fox came from Tim Carmody, the author of a very interesting article called simply "Synergy killed the Fantastic Four." As Carmody is suggesting, it is crucial to Marvel executives to actually sustain a specific discourse around the $F F$ cancelation that underlines the comic-book-driven reasons for the series fading and includes no negative comments about the Fox involvement. It is true, however, that The World's Greatest Comic Magazine gradually lost readership, with a brief boost during Hickman's take on the title between 2009 and 2012 that quickly faded afterwards. Marvel's strategy here is to promote the strictly commercial decision about $F F$ 's cancelation that Brevoort himself is formulating as: "Of the people who are complaining the loudest about the series sunsetting, most of them haven't read the title regularly in years." 12

Carmody is suggesting, however, that there still exists quite a legitimate trope to describe fictional Secret Wars as a narrativization of real "synergy wars" between Fox and Marvel that stand for the actual decision about abandoning the comic $F F$ title. To find such a connection, we have to decipher the main antagonists of Secret Wars - and the whole $F F$ franchise as well - as a graphic model for both companies. The main conflict that involves Mr Fantastic and his biggest adversary - Dr Doom - centers around Dr Doom's main sin, which Reed identifies as being "so afraid of losing the things you've saved that you hold them too tight." ${ }^{13}$ Dr Doom, as a self-proclaimed god of the so-called Battleworld - a fictional world that comes into being from the catastrophic synergy (sic!) of all the Marvel comics variants of its multiverse - is presented in Secret Wars as a ruthless tyrant that shapes this new hybrid territory according to his selfish will. At the same time, Dr Doom's imagination seems to be too limited for being a leader, as Black Panther — one of the Marvel heroes — tells him earlier: "raising up a new [Marvel Universe - T.Ż.] would require a vision you just don't possess." ${ }^{\prime 14}$ It is hard not to see here the obvious anti-Fox rhetoric that takes the shape of a malevolent villain who finally gains absolute control over the other Marvel

12 T. Carmody, "Synergy killed the Fantastic Four," Verge, http://www.theverge.com/2016/1/19/ 107904-50/marvel-secret-wars-comics-heroes-goodbye-fantastic-four (accessed: 27.07.2016).

13 Ibid.

14 Ibid. 
"properties." The metafictional message is obvious: "a comic book world needs to grow and evolve and not simply cycle through every conceivable permutation of a conflict between existing properties." 15 The most clear manifesto of Marvel's approach to Fox's "tyrant" and "poorly conceived" universe appears when "Doom finally admits that with the same power, tempered by compassion and guided by imagination, Reed Richards would have done a better job at saving everything [i.e. the, Marvel universe as a whole]." 16 As the most memorable quote from $\mathrm{Se}$ cret Wars battles underlines: "For holding a thing... shaping a thing... does not make it yours forever... Things change... They evolve..." ${ }^{17}$ Once again, there is a strong temptation here to treat these words as an act of accusation against Fox.

But is this the conclusion of the Fox-Marvel more-or-less-official rivalry over the selected properties? As the history of popular culture teaches us, there is almost never a definite resolution for such conflicts - especially if the goals of two rivals are basically the same and they are concerned mostly with profit and the creative expansion of the selected franchise. Even now there are some legitimate rumors about the possible forms of co-operation between the two companies, although their scale is not yet as profound as most of the comic book fans would like it to be. It is a fact, however, that the first joint venture between Fox and Marvel with the controversial material, $X$-Men universe, will take shape as a TV series called Legion that had its premiere in the fall of 2016. This production concentrates on the character of David Haller/Legion who is a mutant and one of the X-Men members. The character itself falls under Fox's jurisdiction and thus obviously there are Fox's X-Men producers Lauren Shuler Donner, Bryan Singer and Simon Kinberg on board as executive producers. At the same time, Legion has enlisted the Executive Vice President of Marvel Television, Jeph Loeb, along with Marvel TV producer, Jim Chory, to co-operate for the show. The real question here is: does it foreshadow a real re-shaping process of the Fox-Marvel approach? As the recent example of the $X$-Men comic books diminishing has shown - rather not. Although, once again, there is nothing truly certain here as the recent deal between Sony and Marvel has shown. If the absolutely iconic character of Spider-Man could finally find its way to go back to the Marvel Studios then maybe there is still hope for $F F$ ? If that idea will ever come to life it is important to note that this re-conception of Marvel's First Family will have to take place completely according to Marvel's modern internal synergy oriented around its Cinematic Universe. That means some crucial changes for the whole $F F$ initial idea as the Marvel Universe is more earthbound than it had ever been and that is why $F F$ can no longer interact with the universe they founded and shaped. $F F$ was first published in 1961 - it was a time of both apprehension and optimism, particularly for science, and

\footnotetext{
15 Ibid.

16 Ibid.

17 J. Hickman, E. Ribić, "Secret Wars” \#4, Marvel Comics 2015, p. 19.
} 
for which space exploration was the ultimate symbol of progress. If the $F F$ are to return, they have to return transformed as Brevoort says: "nostalgia by itself isn't enough." 18 There is of course a lot of potential topics that can include heroes like $F F$ in Marvel Cinematic Universe, i.e. climate change or economic crisis instead of strictly cosmic adventures. Fans of $F F$ should definitely not give up hope then, as Brevoort himself admits:

We live in a world in which Ant-Man and Guardians of the Galaxy are blockbuster movies. So I think it's only a matter of time until we see [the Fantastic Four] again. ${ }^{19}$

The main question of this article was: what can popular comics say about the modern transmedia universes? I believe that the proper answer to this question is quite a paradoxical one: it should admit that popular comics - despite their central role in creating most of today's synergical franchises - are becoming less and less important in the whole transmedia strategy model. It is quite a shame that a medium that spawned so many popular features - that often are not even recognized by the mass audience as comic-related - is so marginalized. However, at the same time it is not an entirely abandoned area as popular comics are still offering narratives that in some way are referring to its diminishing role. We can find such an example in Marvel's Secret Wars and the whole comic book's discourse around $F F$ 's disappearance. The final remark should be to actually underline the efforts to re-discover popular comics as important areas of an industry's knowledge and a bank of vivid metaphors that can help us to understand the sometimes illogical paths of the modern popular culture with its original mechanisms such as the anti-synergy model described above.

\section{Zagłada "Fantastycznej Czwórki". O zniknięciu Pierwszej Rodziny Marvela i jego znaczeniu dla postrzegania komiksu popularnego w perspektywie transmedialnej}

Abstrakt

Historia medialnych migracji marki o tytule „Fantastyczna Czwórka” może wydać się nawet bardziej emocjonująca niż same przygody tej rodziny superbohaterów stworzonych przez legendarny duet Stana Lee i Jacka Kirby’ego. Będąc pierwotnie fundamentem, na którym oparto całe uniwersum komiksów wydawnictwa Marvel, czwórka herosów przeszła daleką drogę, trafiając do seriali telewizyjnych, kreskówek, gier wideo i wreszcie kinowych produkcji. W przeciwieństwie jednak do swoich „towarzyszy” pokroju Spider-Mana czy grupy X-Men Fantastycznej Czwórce nie wiodło się zbyt dobrze w pozakomiksowym środowisku, czego symbolicznym przykładem stały

18 T. Carmody, op. cit.

19 Ibid. 
się — uważane dziś za na wskroś nieudane — projekty filmowe Rogera Cormana czy Josha Tranka. W podtekście niefortunnych poczynań Fantastycznej Czwórki znajduje się jednak ukryta narracja obrazująca silne uzależnienie komiksu amerykańskiego od zewnętrznych czynników kulturowych, ekonomicznych czy medialnych. Jeśli bowiem przyjąć, że komiks superbohaterski stanowi mocno paratekstualny oraz transmedialny fenomen, a historia tego gatunku nie pozwala sądzić inaczej, to na przykładzie serii „Fantastyczna Czwórka” doskonale widać współczesne mechanizmy zarządzania marką tego pokroju w kontekście konkurowania o prawa autorskie (co obrazuje spięcie na linii koncernów Marvel-Fox), a także pozakomiksowe sposoby kształtowania percepcji tytułów komiksowych i wreszcie potencjalne straty, jakie medium komiksowe może ponieść poprzez egzystowanie $\mathrm{w}$ transmedialnym środowisku.

W artykule zastanawiam się nad przyczyną ,wygaszenia” serii komiksowej „Fantastyczna Czwórka", a także nad wpływem takich kategorii, jak synergia, franczyza, narracja transmedialna czy konwergencja, na kształt współczesnego rynku komiksowego.

Słowa-klucze: Marvel, Fantastyczna Czwórka, kultura konwergencji, narracja transmedialna

\section{Bibliography}

Browne K.S., "There will officially be NO MORE X-Men in Marvel comics," Movie Pilot, http:// moviepilot.com/posts/3550221 (accessed: 27.07.2016).

Carmody T., "Synergy killed the Fantastic Four," Verge, http://www.theverge.com/2016/1/19/10790450/ marvel-secret-wars-comics-heroes-goodbye-fantastic-four (accessed: 27.07.2016).

Hadsell B., "Explaining Marvel's ongoing feud with Fox over the Fantastic Four and X-Men film rights," Unreality Magazine, http://unrealitymag.com/movies/explaining-marvels-ongoingfeud-with-fox-over-the-fantastic-four-and-x-men-film-rights/ (accessed: 27.07.2016).

Hickman J., Ribić E., "Secret Wars" \#4, Marvel Comics 2015.

Jenkins H., Convergence Culture: When Old and New Media Collides, New York 2006.

Johnson D., Media Franchising: Creative License and Collaboration in the Culture Industries, New York 2013.

Johnston R., "Tom Brevoort semi-confirms reduction in prominence of X-Men at Marvel," Bleeding Cool, http://www.bleedingcool.com/2014/08/02/tom-brevoort-semi-confirms-reduction-inprominence-of-x-men-at-marvel/ (accessed: 27.07.2016).

O'Connell S., "Marvel still sabotaging X-Men and the Fantastic Four," https://www.cinemablend. com/new/Marvel-Still-Sabotaging-X-Men-Fantastic-Four-71801.html (accessed: 27.07.2016).

Rechtshaffen M., "Press views: Fantastic Four," BBC, http://news.bbc.co.uk/2/hi/entertainment/46654 69.stm (accessed: 27.07.2016).

Travers P., "Fantastic Four," Rolling Stone, http://www.rollingstone.com/movies/reviews/fantastic-four-20150806 (accessed: 27.07.2016). 